\title{
Explicit empirical model for photovoltaic devices. Experimental validation
}

\author{
A. Massi Pavan ${ }^{\mathrm{a}, \mathrm{e}, *}, \mathrm{~S}$. Vergura ${ }^{\mathrm{b}}$, A. Mellit ${ }^{\mathrm{c}, \mathrm{d}}$, V. Lughi $^{\mathrm{a}}$ \\ a Department of Engineering and Architecture, University of Trieste, Via A. Valerio, 6/A, 34127 Trieste, Italy \\ ${ }^{\mathrm{b}}$ Department of Electrical and Information Engineering, Politecnico di Bari, 70125 Bari, Italy \\ ${ }^{\mathrm{c}}$ Faculty of Sciences and Technologies, Renewable Energy Laboratory, Jijel University, Jijel 18000, Algeria \\ d Abdus Salam International Centre for Theoretical Physics, Strada Costiera, 11, 34151 Trieste, Italy \\ ${ }^{\mathrm{e}}$ Today with The School of Electrical and Electronic Engineering, The University of Manchester, Manchester, UK
}

\section{A R T I C L E I N F O}

\section{Article history:}

Received 16 December 2016

Received in revised form 22 May 2017

Accepted 3 July 2017

\section{Keywords:}

CdTe

CIGS

HIT

$\mathrm{I}-\mathrm{V}$ and P-V characteristics

\begin{abstract}
A B S T R A C T
A comparison between the experimental current-voltage (I-V) and power-voltage (P-V) characteristics of PhotoVoltaic (PV) modules, and the prediction of an explicit empirical model has been carried out. The model consists of an explicit expression for the current as a function of the voltage; the only inputs are the parameters that are always directly available in the manufacturer's datasheet. The comparison was carried out on four representative PV technologies, based on polycrystalline Si, Heterojunction with Intrinsic Thin layer (HIT), Copper Indium Gallium Selenide (CIGS), and Cadmium Telluride (CdTe). The comparison reveals that the model replicates the experimental I-V and P-V curves to a very good degree of accuracy for the considered operating conditions and PV technologies. This validation sets a turning point in PV modelling, as it enables a reliable use of this accessible model.
\end{abstract}

() 2017 Elsevier Ltd. All rights reserved.

\section{Introduction}

Nowadays, the main commercial Photovoltaic (PV) technology is based on crystalline silicon. These solar devices represent the first generation of photovoltaics and cover the $90 \%$ of the market. The remainder of the market is covered by thin film technologies mainly based on CdTe, CIGS, and amorphous silicon. These products, owning to the second generation of photovoltaics and characterized by a slightly lower efficiency than the devices from the first one, are today entering the market especially because of their lower manufacturing cost and continuous increase in performances (Lineykin et al., 2014). In the future, a third generation of photovoltaics should commercially guarantee higher efficiencies and lower costs. Dye Sensitized Solar Cells (DSSC), Organic PV (OPV), Intermediate electronic Band (IB) and Multiple Exciton Generation (MEG) are only some examples of third generation devices that today are either not commercially available or have a very small market (Choubey et al., 2012). The first and second generation technologies are based on different physical mechanisms, come from a wide range of fabrication techniques,

\footnotetext{
* Corresponding author at: Department of Engineering and Architecture, University of Trieste, Via A. Valerio, 6/A, 34127 Trieste, Italy.

E-mail address: apavan@units.it (A. Massi Pavan).
}

and their electrical output in terms of current and power-voltage characteristics are slightly different.

Effective use of PV modules requires reliable modelling methods, aiming at predicting the behaviour of a PV system at conditions different from those characterized by the manufacturer's datasheet. Such methods are helpful for monitoring the performance (Vergura et al., 2009; Cristaldi et al., 2012, 2015; d'Alessandro et al., 2015) and the losses in solar systems (Massi Pavan et al., 2013; Moballegh and Jiang, 2014; Massi Pavan et al., 2015; Spertino et al., 2015), for forecasting the produced power (Bouzerdoum et al., 2013; Bizzarri et al., 2013; Dolara et al., 2015; Dellino et al., 2015; Chicco et al., 2016), and for development and testing of maximum power point tracking algorithms (Manganiello et al., 2014; Boztepe et al., 2014; Seyedmahmoudian et al., 2015). Reliable models are also needed for system fault diagnosis (Chine et al., 2014, 2016) and to study and evaluate the behaviour of defective PV cells. Description of known defects in PV cells is reported in Breitenstein et al. (2004, 2001), Acciani et al. (2010), while in-depth investigations of the thermal effects of defects are proposed in Vergura et al. (2012, 2009a,b) where a finite element approach to model some classes of defects commonly found in PV cells is presented.

Equivalent circuits, including a photocurrent source, one or more resistors, and one or more nonlinear elements typically represented by semiconductor diodes, are the most common topology 
for modelling crystalline Si PV devices (Duffie and Beckman, 1991). A widely used equivalent circuit is the "single-diode" model often referred to as the "five-parameter" model (Fig. 1), as it may be completely characterized by five parameters: shunt and series resistances, diode ideality factor, photocurrent, and diode reverse saturation current. The single diode model ensures high accuracy through three characteristic points in the PV datasheet (opencircuit voltage, short-circuit current, and maximum power point), it guarantees that the maximum point generated by the mathematical model coincides with the datasheet, and provides an excellent fit between to the experimental current-voltage (I-V) curve (Mahmoud et al., 2013).

The five-parameters model is accurate enough for modelling and simulation of crystalline Si PV modules, but the applicability to other PV technologies (especially owning to the second generation of photovoltaics) is found to be limited since the single-diode equivalent circuit fails to describe the significantly different physical processes of converting radiant energy into electrical energy (Lineykin et al., 2014). For this reason, today many researchers are focusing in the development of new models capable of describing the behaviour of different technologies, such as for example thin-films (Miceli et al., 2015).

The explicit empirical model for general PV devices - that was introduced in order to enable modelling based only on the parameters that are always listed in the datasheet of solar devices - overcomes these drawbacks. It was initially introduced in Pavan et al. (2007) and then applied in Massi Pavan et al. (2014a), Barbini et al. (2014) in a revised form for assessing the mismatch effect due to the use of different classes of PV modules in large-scale solar parks. A revised form of the model was validated experimentally for operation at Maximum Power Point (MPP) (Massi Pavan et al., 2014b), showing a very good prediction performance, better than the ones obtained with the golden standard in PV modelling, i.e. the five-parameters model. The explicit empirical model has been lately improved, introducing a correction factor that leads to a good match with the experimental electrical characteristics also for operating points other than the MPP (Vergura and Massi Pavan, 2015).

As mentioned, the model is based exclusively on the parameters commonly found in the datasheets provided by the manufacturers, and is explicit - and therefore quite easy to implement in computer-aided calculations. Explicit models are today increasingly being studied (Batzelis et al., 2014) due to these characteristics, and they represent a useful tool not only for scientists, but also in all practical cases for PV plant designers, Operation and Maintenance $(\mathrm{O} \& \mathrm{M})$ personnel, and in general for PV professionals. In particular, the model has a distinct advantage in terms of computational complexity and time, both because its explicit form, and because the input parameters are readily available and do not need to be computed in advance (see for example Sandrolini et al., 2010; Chatterjee et al., 2011; Lo Brano et al., 2010; Saleem and Karmalkar, 2009; Bouzidi et al., 2007; Ortiz-Conde et al., 2003; Amit and Kapoor, 2004; Ishaque et al., 2011; Vergura, 2016).

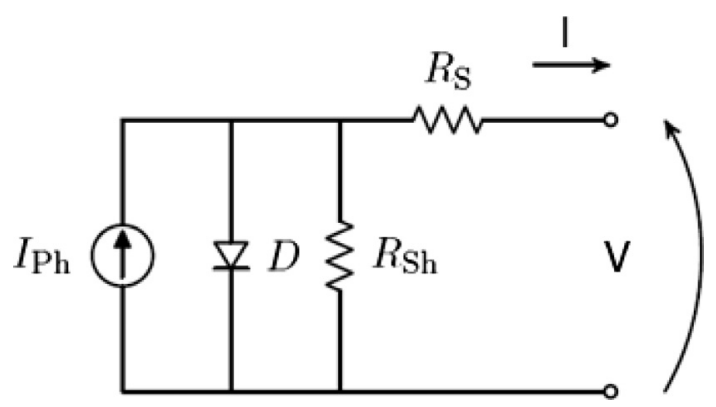

Fig. 1. Solar cell equivalent circuit - five-parameters model.
Validation of this model along the entire I-V and P-V characteristics is therefore of paramount importance for ensuring that this very accessible tool does have the necessary accuracy and reliability for professional and scientific purposes. In this work, we focus on the validation of the model for the entire current-voltage (I-V) and power-voltage $(\mathrm{P}-\mathrm{V})$ characteristics of four representative commercial PV modules based on polycrystalline silicon, HIT technology, CIGS, and CdTe. With reference to the solar irradiance, the validation was carried out in the range $\left[900-1000 \mathrm{~W} / \mathrm{m}^{2}\right]$.

The paper is organized as follows: the next Section is on the description of the model under validation. Section 3 presents the test facility. Section 4 deals with results and discussion. Section 5 presents the conclusions.

\section{The explicit empirical model}

The behaviour of a solar cell is commonly modelled with the well-known five-parameter equivalent model represented in Fig. 1.

The solar cells is modelled by an ideal current source in parallel with a diode. The circuit is described by the following equation:

$I=I_{P h}-I_{o} \times\left[e^{\left(V+I R_{s}\right) / n V_{t}}-1\right]-\frac{V+I R_{S}}{R_{s h}}$

where $I_{P h}(A)$ is the light generated current (i.e. the short circuit current neglecting the parasitic resistances), $I_{0}(A)$ is the dark saturation current due to recombination, $\mathrm{n}$ is the ideality factor, $\mathrm{V}_{\mathrm{t}}(\mathrm{V})$ is the thermal voltage, $R_{s}(\Omega)$ is a series resistance, and $R_{s h}(\Omega)$ is a shunt resistance. The light generated current is directly proportional to the solar irradiance (Townsend et al., 1989):

$I_{P h}=\frac{G}{1000} \times\left[I_{\text {Lref }}+\alpha \cdot\left(T_{c}-25\right)\right]$

where $\mathrm{G}\left(\mathrm{W} / \mathrm{m}^{2}\right)$ is the solar irradiance, $1000 \mathrm{~W} / \mathrm{m}^{2}$ is the solar irradiance at Standard Test Conditions (STC), $\mathrm{I}_{\text {Lref }}(\mathrm{A})$ is the short circuit current at STC, $\alpha\left(\mathrm{A} /{ }^{\circ} \mathrm{C}\right)$ is the current-temperature coefficient at STC, $\mathrm{T}_{\mathrm{c}}\left({ }^{\circ} \mathrm{C}\right)$ is the cell temperature and $25^{\circ} \mathrm{C}$ is the STC cell temperature.

Combining Eqs. (1) and (2), we can write:

$I=\frac{G}{1000} \times\left[I_{\text {Lref }}+\alpha \cdot\left(T_{c}-25\right)\right]-I_{o} \times\left[e^{\left(V+I R_{s}\right) / n V_{t}}-1\right]-\frac{V+I R_{S}}{R_{S h}}$

The dark saturation current $I_{0}$ is a function of the cell temperature and can be written as (Kichou et al., 2016):

$I_{o}=I_{\text {oref }} \cdot e^{\left(\begin{array}{ll}E_{g_{0}} & E_{g} \\ V_{t o}- & V_{t}\end{array}\right)} \cdot\left(\frac{T_{c}}{25}\right)^{3}$

where $I_{\text {oref }}(A)$ and $V_{\text {to }}(V)$ are the saturation current and the thermal voltage at STC, respectively, $E_{g}(V)$ is the energy bandgap, while $\mathrm{E}_{\mathrm{go}}(\mathrm{V})$ is the energy bandgap at $\mathrm{T}=0 \mathrm{~K}$. Combining Eqs. ( 3 ) and (4), we can write:

$$
\begin{aligned}
I= & \frac{G}{1000} \times\left[I_{L r e f}+\alpha \cdot\left(T_{c}-25\right)\right]+I_{\text {oref }} \cdot e^{\left(\frac{E g o}{V_{t o}}-\frac{E_{g}}{V_{t}}\right)} \cdot\left(\frac{T_{c}}{25}\right)^{3} \\
& -I_{\text {oref }} \cdot\left(\frac{T_{c}}{25}\right)^{3} \cdot e^{\left(\frac{E_{g o}}{V_{\text {to }}}-\frac{E_{g}}{V_{t}}+\frac{\left(V+R R_{s}\right)}{n \cdot V_{t}}\right)}-\frac{V+I R_{s}}{R_{s h}}
\end{aligned}
$$

The series resistance $R_{S}$ is also a function of the operating conditions being (Markvart and Castaner, 2006):

$R_{S}=\frac{V_{O C}}{I_{S C}} \times r_{s}$

where $V_{o c}(V)$ and $I_{s c}(A)$ are the open circuit voltage and the short circuit current at arbitrary conditions of solar irradiance and cell 
temperature respectively, and $r_{s}$ is the normalized solar cell's resistance.

The open circuit voltage $\mathrm{V}_{\text {oc }}$ depends on the cell temperature and can be written as (Luque and Hegedus, 2003):

$V_{O C}=V_{O C, S T C}+\beta \cdot\left(T_{C}-25\right)$

where $\mathrm{V}_{\mathrm{OC}, \mathrm{STC}}(\mathrm{V})$ is the open circuit voltage at STC and $\beta\left(\mathrm{V} /{ }^{\circ} \mathrm{C}\right)$ is the voltage-temperature coefficient at STC.

Finally, the short circuit current $\mathrm{I}_{\mathrm{sc}}$ depends on the solar irradiance and can be written as (Ishaque et al., 2011):

$I_{S C}=\frac{G}{1000} \times I_{S C, S T C}$

where $\mathrm{I}_{\mathrm{SC} \text { STC }}(\mathrm{A})$ is the short circuit current at STC.

Substituting (7) and (8) in (6), then (6) in the third and fourth term of (5), we obtain:

$$
\begin{aligned}
I= & \frac{G}{1000} \times\left[I_{\text {Lref }}+\alpha \cdot\left(T_{c}-25\right)\right]+f_{1}(V)+f_{2}\left(I, G, T_{c}\right) \\
& +\exp \left(V, I, G, T_{c}\right)
\end{aligned}
$$

where $f_{1}$ is a linear function of the voltage, $f_{2}$ is a function of the current and the operating conditions (thus similar to the first term of Eq. (5)), and the exponential depends on both the electrical variables and on the operating conditions. These three functions can be grouped in an empiric expression able to provide a correct current value for each voltage value in the range $\left[0-\mathrm{V}_{\mathrm{OC}}\right]$, whatever the environmental condition is:

$$
\begin{gathered}
f_{1}(V)+f_{2}\left(I, G, T_{c}\right)+\exp \left(V, I, G, T_{c}\right) \\
=-\frac{G}{1000} \cdot \frac{e^{m \cdot\left[V-\beta \cdot\left(25-T_{c}\right)\right]}-1}{e^{m}-1}
\end{gathered}
$$

where $\mathrm{m}$ is an empiric exponential factor.

Combining (9) and (10), a more suitable empirical expression where the current and the voltage are in a per unit representation (Vergura and Massi Pavan, 2015) is:

$I_{p u}=\frac{G}{1000}\left[I_{L, r e f}+\alpha \cdot\left(T_{c}-25\right)-\frac{e^{m \cdot\left[V_{p u}-\beta \cdot\left(25-T_{c}\right)\right]}-1}{e^{m}-1}\right]$

where $I_{p u}$ (p.u.) is the per unit current referred to $I_{S c, S T C}, I_{L, r e f}$ (p.u.) is the per unit irradiance referred to $1000 \mathrm{~W} / \mathrm{m}^{2}, \mathrm{~V}_{\mathrm{pu}}$ (p.u.) is the per unit voltage referred to $\mathrm{V}_{\mathrm{OC}, \mathrm{STC}}, \alpha^{\prime}\left(1 /{ }^{\circ} \mathrm{C}\right)$ is the current-temperature coefficient referred to $\mathrm{I}_{\mathrm{SC}, \mathrm{STC}}\left(\alpha^{\prime}=\alpha / \mathrm{I}_{\mathrm{SC}, \mathrm{STC}}\right)$ and $\beta^{\prime}\left(1 /{ }^{\circ} \mathrm{C}\right)$ is the voltage-temperature coefficient referred to $\mathrm{V}_{\mathrm{OC}, \mathrm{STC}}\left(\beta^{\prime}=\beta / \mathrm{V}_{\mathrm{OC}, \mathrm{STC}}\right)$.

The model represented by Eq. (11) has a wide applicability and presents the following pros:

- It can be used considering only the electrical parameters which can always be found in the solar cell/PV module datasheet. This represents a clear advantage as the commonly used models require parameters that cannot be found in the manufacturer's datasheets, such as the light-generated or PV current, the series and shunt resistances, the diode ideality constant, the diode reverse saturation current, and the bandgap energy of the semiconductor (Villalva et al., 2009).

- It is explicit, which is a very desirable feature for simulation applications, especially when the model is to be used repeatedly (as, for example, in the case of PV emulators (Massi Pavan et al., 2009). Simulation times can be significantly reduced by avoiding the numerical iterations required by implicit equation models (Ortiz Conde et al., 2012).

- It can be used for any type of PV technology belonging to first and second generation photovoltaics as, for example, crystalline $\mathrm{Si}, \mathrm{CdTe}, \mathrm{CIGS}$, etc.

- It can be used for any type of PV device: solar cells, PV modules, PV strings and fields. The extension to the model to these latter has been shown in Massi Pavan et al. (2014a) and comes from the Kirchhoff's laws and the induction principle.

- It can be used to calculate any operating conditions of the I-V and P-V characteristics (generic, at MPP, and in open and short circuit configurations) for high levels of solar irradiance.

\section{Validation of the explicit empiric model}

The empirical model has been tested starting from the I-V and P-V characteristics of four PV modules mounted in our Laboratory (Massi Pavan et al., 2014c). The four PV modules are representative of different technologies: polycrystalline $\mathrm{Si}, \mathrm{CdTe}, \mathrm{CIGS}$, and HIT. The solar cells of this latter are made of a thin mono crystalline silicon wafer surrounded by ultra-thin amorphous silicon layers. The different parameters of the considered PV devices are reported in Table 1.

The following instruments have been used to measure and log the different working conditions:

- An ISO9060 first class thermopile global radiometer type C100RDPA153 from LSI Lastem S.r.l. measuring the global solar irradiance (with a daily uncertainty less than 5\%).

- A contact probe type DLE124 produced by LSI Lastem S.r.l. (with an accuracy of $\pm 0.15^{\circ} \mathrm{C}$ ).

- Two data loggers type E-Log produced by LSI Lastem S.r.l.

- A shunt type SHP300A60-Compact produced by Hobut Ltd. calibrated with an accuracy better than $0.01 \%$.

Fig. 2 shows two of the considered PV modules, while in Fig. 3 the data logger and the shunt are visible.

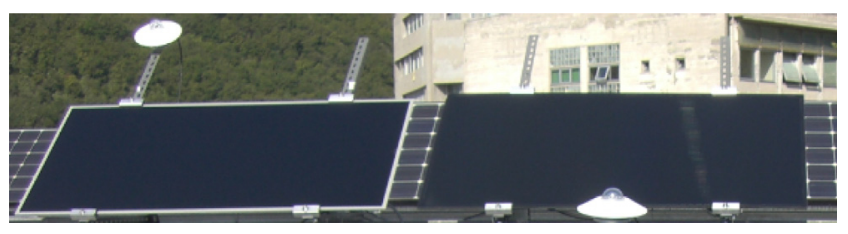

\begin{tabular}{|c|c|c|c|c|}
\hline Photovoltaic module & Q.Pro & HIP 215NHE5 & UF-95 & FS-272 \\
\hline Material technology & Poly-Si & HIT & CIGS & CdTe \\
\hline Nominal power $P_{n}(W)$ & 230 & 215 & 95 & 72.5 \\
\hline Tolerance on the nominal power (W) & $+5 /-0 \%$ & $+10 /-5 \%$ & $+5 /-0 \%$ & $\pm 5.0 \%$ \\
\hline Short circuit current $\mathrm{I}_{\mathrm{SC}}(\mathrm{A})$ & 8.30 & 5.61 & 1.68 & 1.23 \\
\hline Open circuit voltage $\mathrm{V}_{\mathrm{OC}}(\mathrm{V})$ & 36.6 & 51.6 & 78.0 & 88.7 \\
\hline Current at maximum power point $\mathrm{I}_{\mathrm{mp}}(\mathrm{A})$ & 7.84 & 5.13 & 1.53 & 1.09 \\
\hline Voltage at maximum power point $\mathrm{V}_{\mathrm{mp}}(\mathrm{V})$ & 29.6 & 42.0 & 62.1 & 66.6 \\
\hline Current/temperature coefficient $\alpha(\% / \mathrm{K})$ & +0.04 & +0.03 & 0.00 & +0.04 \\
\hline Voltage/temperature coefficient $\beta(\% / \mathrm{K})$ & -0.41 & -0.03 & -0.38 & -0.25 \\
\hline NOCT $\left({ }^{\circ} \mathrm{C}\right)$ & 47 & 48 & 51 & 45 \\
\hline
\end{tabular}

Fig. 2. The CdTe and CIGS PV modules used in the test.

Table 1

Electrical characteristics at STC (except for NOCT). 


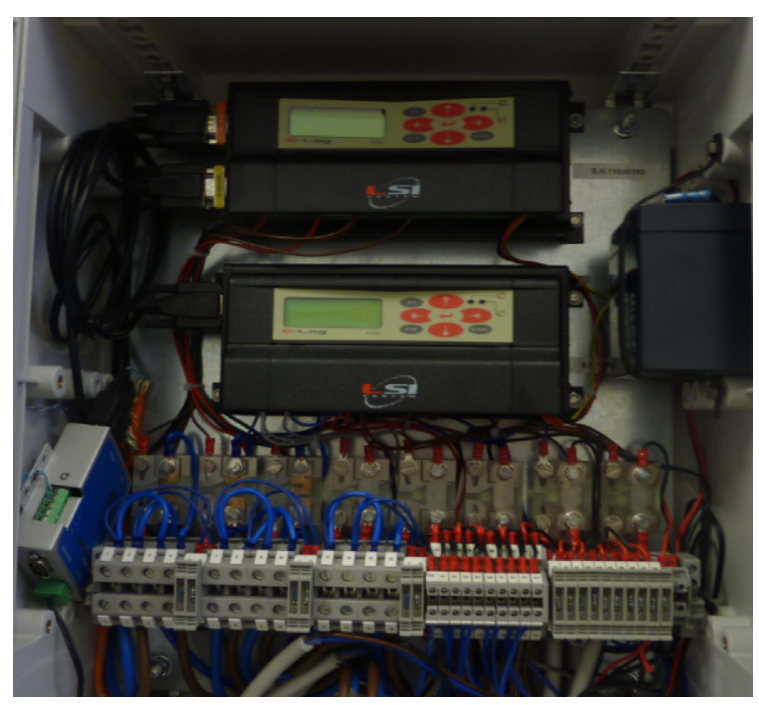

Fig. 3. Particular of the data acquisition system.

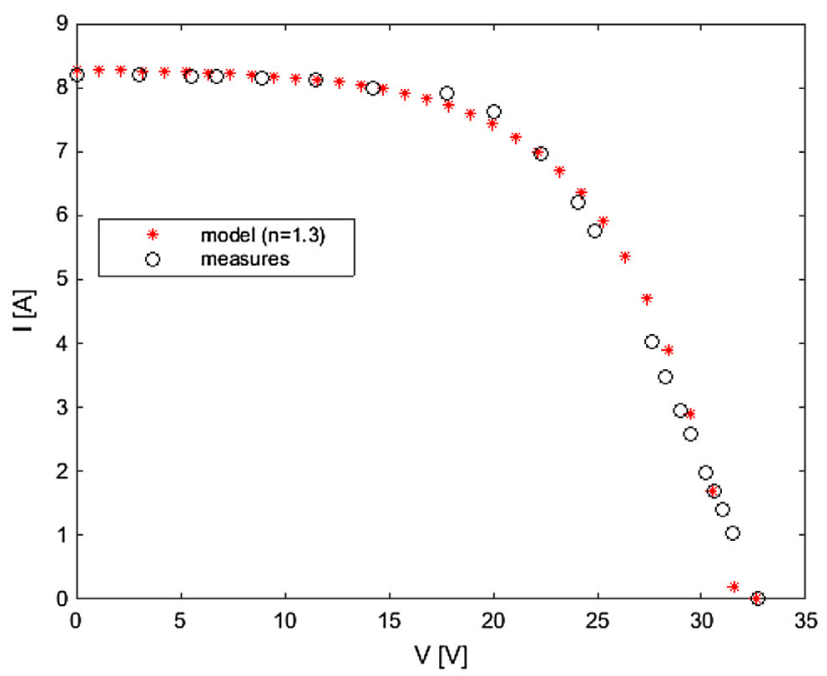

(a)

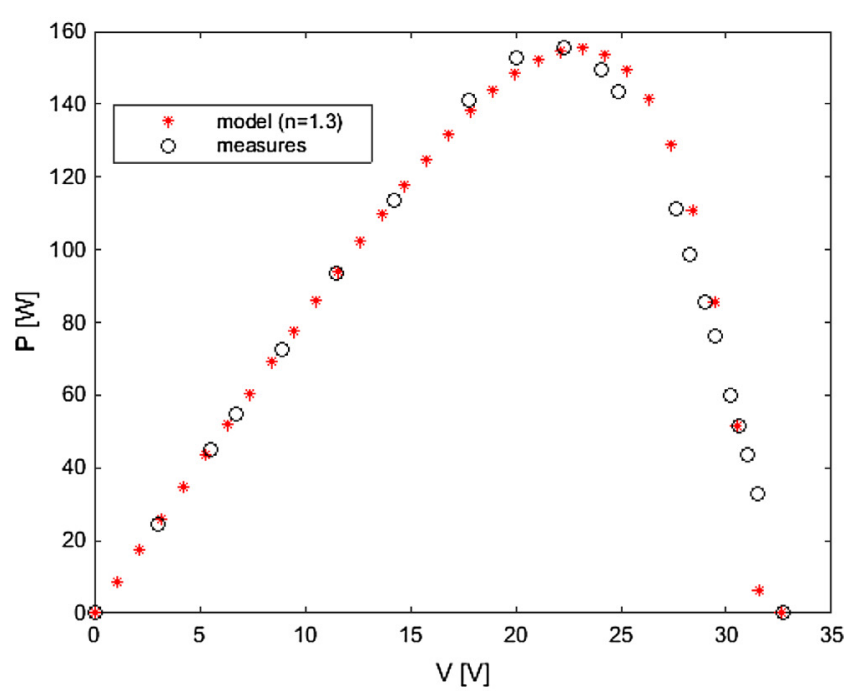

(b)

Fig. 4. Characteristics for the Q.Pro module ( $\mathrm{n}=1.3$ Yildıran and Tacer, 2016), $\mathrm{G}=916 \mathrm{~W} / \mathrm{m}^{2}, \mathrm{~T}_{\mathrm{c}} 57^{\circ} \mathrm{C}$ : (a) I-V curve; (b) P-V curve.
The I-V curves have been plotted using a variable resistive load. Voltages and currents have been measured using the test facility described in Massi Pavan et al. (2014c). The voltages are measured with an accuracy better than $0.01 \%$, while the currents have an accuracy better than $0.1 \%$.

\section{Results}

This section presents the comparison between the I-V and P-V characteristics evaluated by the empirical model and those obtained from the experimental measurements. The solar irradiance is in the range [900-1000 W/ $\left./ \mathrm{m}^{2}\right]$.

Figs. from 4 to 7 depict the I-V and P-V characteristics for the Q. Pro, HIP 215 NHE5, UF-95, and FS-272 modules respectively. For each PV technology, a different value of ideality factor has been used according to Yildıran and Tacer (2016).

The analysis of the eight plots show a fully satisfactory correspondence between the measured and the estimated curves. With reference to the Sanyo HIP module, a slightly overestimated short circuit current and a slightly underestimated open circuit voltage can be noticed. From a quantitative point of view, the results are

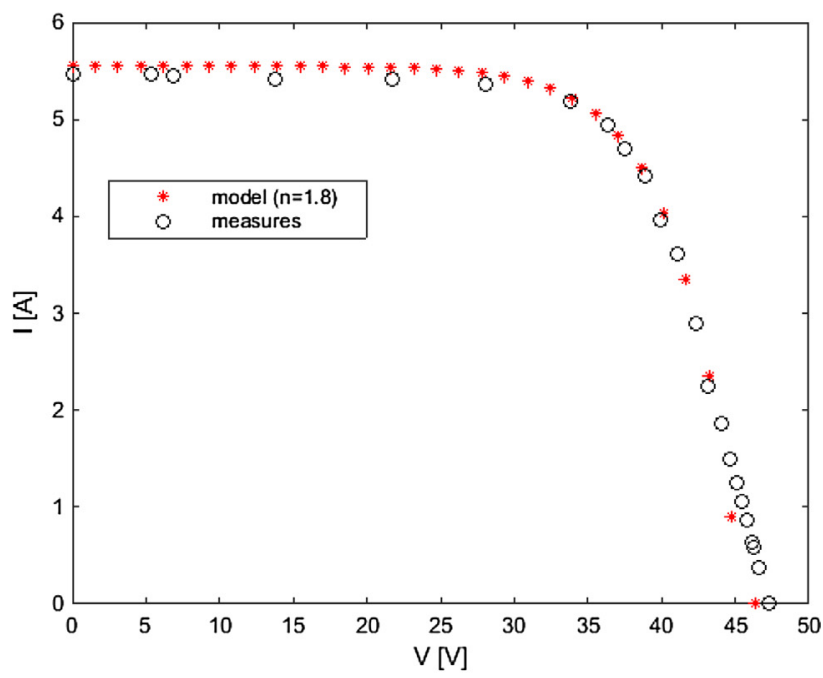

(a)

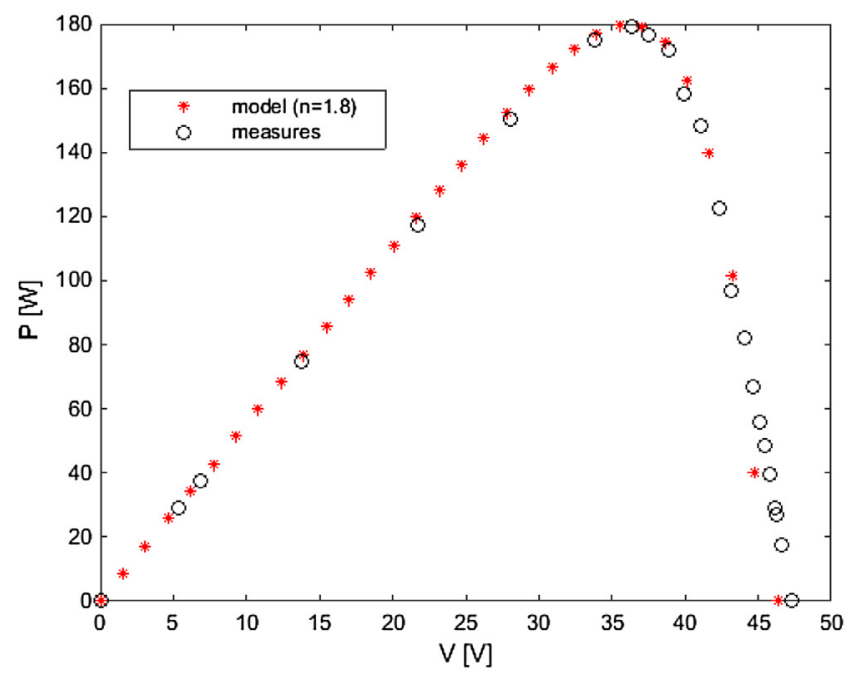

(b)

Fig. 5. Characteristics for the HIP215NHE5 ( $\mathrm{n}=1.8$ Yildıran and Tacer, 2016), $\mathrm{G}=976 \mathrm{~W} / \mathrm{m}^{2}, \mathrm{~T}_{\mathrm{c}} 57^{\circ} \mathrm{C}$ : (a) I-V curve; (b) P-V curve. 


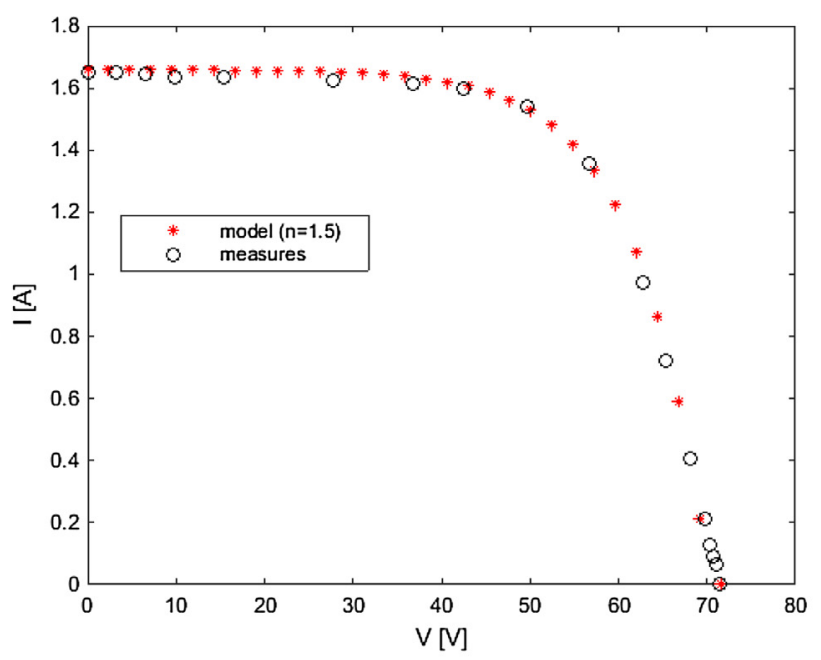

(a)

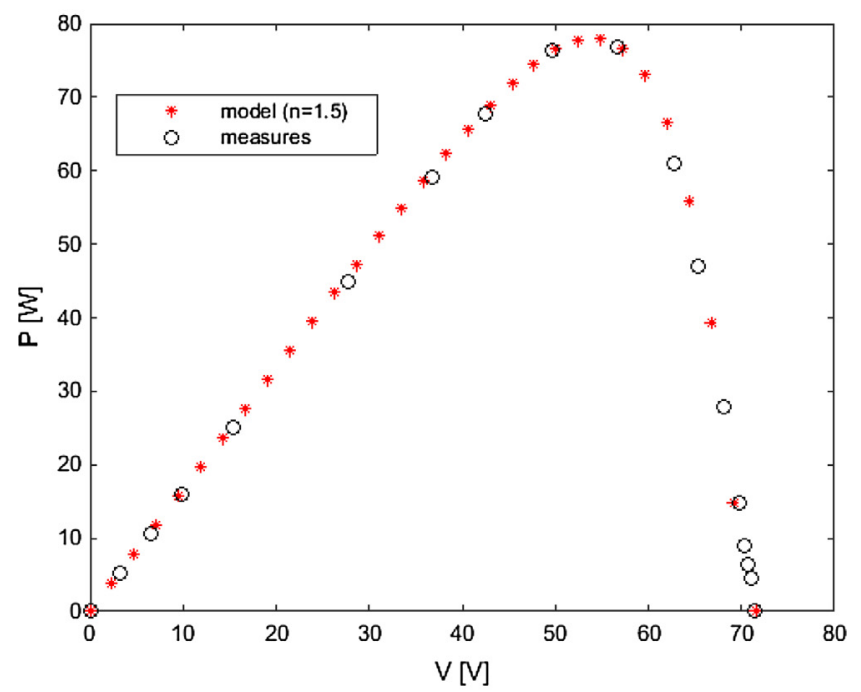

(b)

Fig. 6. Characteristics for the UF95 ( $n=1.5$ Yıldıran and Tacer, 2016), $\mathrm{G}=970 \mathrm{~W} / \mathrm{m}^{2}, \mathrm{~T}_{\mathrm{c}} 58^{\circ} \mathrm{C}$ : (a) I-V curve; (b) P-V curve.

given in terms of statistical errors. The coefficient of determination $\mathrm{R}^{2}$ and the root mean square deviation RMSD are listed in Table 2. The obtained coefficient of determination, consistently larger than 0.98 and mostly equal to 0.99 , show the high performance of the explicit empirical model for any technology. We have also computed the Absolute Percentage Errors (APE) for the main points of the I-V characteristics between the measured and estimated values, respect to the measured ones (Table 3). The measures (acquired with an accuracy of $0.01 \%$ for the voltage and $0.1 \%$ for the current) do not affect the APE values.

Moreover, we have compared the accuracy of the proposed model with the accuracy of the $\mathrm{R}_{\mathrm{p}}$-model and of the two-diode models of Ishaque et al. (2011), considering the errors reported in the last two columns of Tables 5 and 7 (Poly-Si and thin film, respectively) and Figs. 12-13 presented in the same work. Table 4 compares the errors of the proposed model with of the other two models reported in Ishaque et al. (2011). As it can be observed, the proposed model has a limited error, comparable with that of well-established models.

Summarizing, the proposed model performs well at the considered high level of solar irradiance. In some cases a mismatch is observed. We speculate that this limitation is due to the

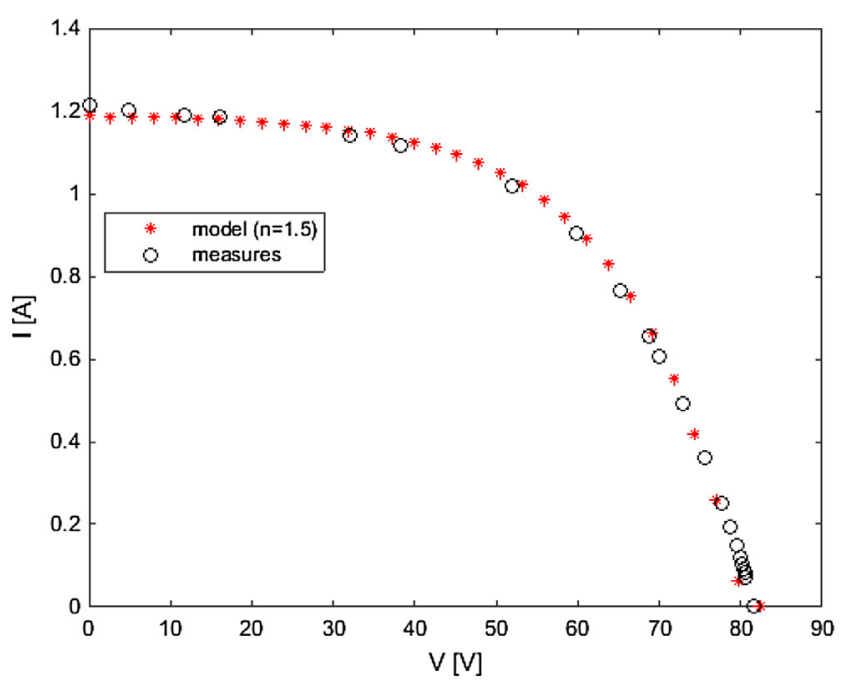

(a)

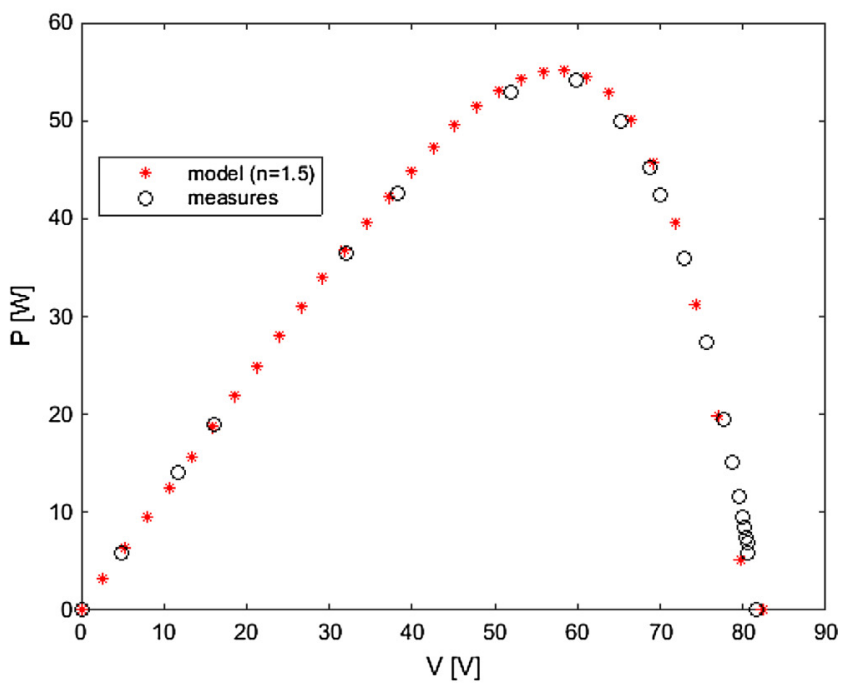

(b)

Fig. 7. Characteristics for the FS-272 ( $\mathrm{n}=1.5$ Yıldıran and Tacer, 2016), $\mathrm{G}=936 \mathrm{~W} / \mathrm{m}^{2}, \mathrm{~T}_{\mathrm{c}} 56^{\circ} \mathrm{C}$ : (a) I-V curve; (b) P-V curve.

Table 2

Statistical errors.

\begin{tabular}{|c|c|c|c|c|c|c|}
\hline \multirow[b]{2}{*}{ PV module } & \multicolumn{2}{|l|}{ Power } & \multicolumn{3}{|l|}{ Current } & \multirow{2}{*}{$\begin{array}{l}\text { Voltage } \\
\mathrm{R}^{2}\end{array}$} \\
\hline & RMSD (W) & $\mathrm{R}^{2}$ & RMSD (W) & $\mathrm{R}^{2}$ & RMSD (W) & \\
\hline Q.PRO & 5.92 & 0.99 & 0.24 & 0.99 & 2.43 & 0.98 \\
\hline HIP215NHE5 & 6.14 & 0.99 & 0.15 & 0.99 & 3.27 & 0.98 \\
\hline UF-95 & 1.64 & 0.99 & 0.03 & 0.99 & 1.72 & 0.98 \\
\hline FS-272 & 1.15 & 0.99 & 0.03 & 0.99 & 0.63 & 0.99 \\
\hline
\end{tabular}

single-diode equation, used to derive the proposed model. A more accurate starting model, such as the double-diode model is expected to perform better, but it would require two empirical indexes, $m_{1}$ and $m_{2}$, to follow the characteristic curves of the two diodes, thus complicating the proposed model, which now is effective and fast, because it does not require any iterative approach, as it happens for other models. With reference to low levels of solar irradiance, and especially for the CdTe technology (Nofuentes et al., 2014; Torres Ramírez et al., 2014), the empirical model can be used but taking into account the influence of the 
Table 3

Absolute percentage errors (APE).

\begin{tabular}{|c|c|c|c|c|c|c|}
\hline & $\mathrm{V}_{\mathrm{oc}}$ & $\mathrm{I}_{\mathrm{sc}}$ & $\mathrm{V}_{\mathrm{mp}}$ & $\mathrm{I}_{\mathrm{mp}}$ & $\mathrm{P}_{\mathrm{MPP}}$ & $\mathrm{FF}$ \\
\hline & \multicolumn{6}{|c|}{ PV module : Q.PRO } \\
\hline Measured & 32.70 & 8.21 & 22.30 & 6.96 & 155.3 & 0.57 \\
\hline Estimated & 32.62 & 8.27 & 23.15 & 6.85 & 158.7 & 0.58 \\
\hline \multirow[t]{2}{*}{ APE (\%) } & 0.22 & 0.82 & 3.83 & 1.62 & 2.15 & 1.54 \\
\hline & \multicolumn{6}{|c|}{ PV module : HIP215NHE5 } \\
\hline Measured & 47.30 & 5.55 & 36.30 & 4.93 & 179.1 & 0.69 \\
\hline Estimated & 46.33 & 5.47 & 35.53 & 4.89 & 173.9 & 0.68 \\
\hline \multirow[t]{2}{*}{ APE (\%) } & 2.04 & 1.40 & 2.14 & 0.76 & 2.88 & 2.23 \\
\hline & \multicolumn{6}{|c|}{ PV module : UF-95 } \\
\hline Measured & 71.50 & 1.65 & 56.60 & 1.36 & 76.8 & 0.65 \\
\hline Estimated & 71.61 & 1.66 & 54.89 & 1.44 & 78.7 & 0.66 \\
\hline \multirow[t]{2}{*}{$\mathrm{APE}(\%)$} & 0.15 & 0.41 & 3.01 & 6.01 & 2.83 & 2.25 \\
\hline & \multicolumn{6}{|c|}{ PV module: FS-272 } \\
\hline Measured & 81.70 & 1.21 & 59.9 & 0.90 & 54.1 & 0.54 \\
\hline Estimated & 82.40 & 1.16 & 58.48 & 0.95 & 55.8 & 0.58 \\
\hline APE (\%) & 0.86 & 4.75 & 2.37 & 5.69 & 3.18 & 7.40 \\
\hline
\end{tabular}

Table 4

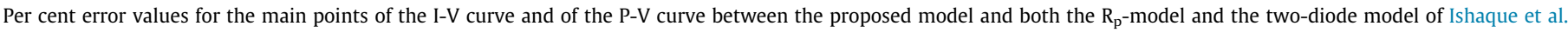
(2011).

\begin{tabular}{|c|c|c|c|c|}
\hline Technology & PV module & $\mathrm{APE}_{\mathrm{Pmp}}$ & $\mathrm{APE}_{\mathrm{Vmp}}$ & $\mathrm{APE}_{\mathrm{Voc}}$ \\
\hline \multirow[t]{3}{*}{ Poly-Si } & Q.PRO (proposed model) & $2.15 \%$ & $3.83 \%$ & $0.22 \%$ \\
\hline & S36/KC200GT ( $\mathrm{R}_{\mathrm{p}}-$ model) (Amit and Kapoor, 2004) & 0.219 & 2.055 & 0.2 \\
\hline & S36/KC200GT (two-diode model) (Amit and Kapoor, 2004) & 0.156 & 1.369 & 0.1 \\
\hline \multirow[t]{4}{*}{ Thin film } & UF-95 (proposed model) & $2.83 \%$ & $3.01 \%$ & $0.15 \%$ \\
\hline & FS-272 (proposed model) & $3.18 \%$ & $2.37 \%$ & $0.86 \%$ \\
\hline & ST40/SQ150PC ( $\mathrm{R}_{\mathrm{p}}$-model) (Amit and Kapoor, 2004) & 0.912 & 1.418 & 1.2 \\
\hline & ST40/ SQ150PC (two-diode model) (Amit and Kapoor, 2004) & 0.853 & 0.709 & 0.9 \\
\hline
\end{tabular}

angle of incidence and the spectral effect in the value of the solar irradiance.

\section{Conclusions}

This paper presents the experimental validation of the explicit empirical model for general PV devices.

The model was tested at different operating points corresponding to high values of solar irradiance. Moreover, the tests were performed on four different representative PV technologies, i.e. polycrystalline $\mathrm{Si}, \mathrm{HIT}, \mathrm{CIGS}$, and CdTe - belonging to the first and the second generation of photovoltaic technologies, respectively.

The model, that had already been tested at maximum power point (Massi Pavan et al., 2014b), has shown to be able to predict the key features of the actual I-V and P-V characteristics to a very good degree of approximation. The curves measured experimentally almost always lay on the predicted ones and the obtained results in terms of statistical errors quantitatively confirm the excellent performance of the model.

Thus, the model represents a very useful and accessible tool not only for scientists but also in all practical cases for PV professionals, such as PV plant designers and Operation and Maintenance (O\&M) personnel.

A future work will be focused on the assessment of a new empirical model based on the idea of the two diodes equivalent circuit.

\section{Acknowledgements}

Dr. Vittorio Arcidiacono is acknowledged for his original work on the explicit empirical model.

Q.Cells Italia S.r.l. and its former CEO Dr. Matthias Altieri are kindly acknowledged for financial support of the test facility. Q. Cells SE with Dr. Aurora Tedesco is also acknowledged for providing the PV modules used in the study.
Mr. Paolo Pruni, Mr. Diego Logar, and Mr. Adriano Zibai are acknowledged for their help in the construction of the test facility.

Mr. Maurizio Besenghi is acknowledged for his daily commitment that ensure the correct operations of the Laboratory at the University of Trieste.

The second author would like to thank the International Centre for Theoretical Physics (ICTP), Trieste (Italy) for providing the materials and the computer facilities for performing the present work.

\section{References}

Acciani, G., Falcone, O., Vergura, S., 2010. Typical Defects of PV-cells. IEEE-ISIE 2010, July, 4-7, Bari, Italy, pp. 2745-2749.

Amit, J., Kapoor, A., 2004. Exact analytical solutions of the parameters of real solar cells using Lambert W-function. Sol. Energy Mater. Sol. Cells 81, 269-277.

Barbini, N., Lughi, V., Mellit, A., Massi Pavan, A., Tessarolo, A., 2014. On the impact of photovoltaic module characterization on the prediction of PV plant productivity. IEEE-EVER, 25-27/03/2014, Monaco, France, pp. 1-4.

Batzelis, E.I., Routsolias, I.A., Papathanassiou, S.A., 2014. An explicit PV string model based on the Lambert W function and simplified MPP expressions for operation under partial shading. IEEE Trans. Sustainable Energy 5, 301-312.

Bizzarri, F., Buongiorno, M., Brambilla, A., Gruosso, G., Storti Gajani, G., 2013. Model of photovoltaic power plants for performance analysis and production forecast. IEEE Trans. Sustainable, Energy 4, 278-285.

Bouzerdoum, M., Mellit, A., Massi Pavan, A., 2013. A hybrid model (SARIMA-SVM) for short-term forecasting of a small-scale grid-connected photovoltaic plant. Sol. Energy 98, 226-235.

Bouzidi, K., Chegaar, M., Bouhemadou, A., 2007. Solar cells parameters evaluation considering the series and shunt resistance. Sol. Energy Mater. Sol. Cells 91, 1647-1651.

Boztepe, M., Guinjoan, F., Velasco-Quesada, G., Silvestre, S., Chouder, A., Karatepe, E., 2014. Global MPPT scheme for photovoltaic string inverters based on restricted voltage window search algorithm. IEEE Trans. Ind. Electron. 61 (7), 3302-3312.

Breitenstein, O, Langenkamp, M., Lang O, Schirrmacher, A., 2001. Shunts due to laser scribing of solar cell evaluated by highly sensitive lock-in thermography. Sol. Energy Mater. Sol. Cells, 55-62.

Breitenstein, O., Rakotoniaina, J.P., Al Rifai, M.H., Werner, M., 2004. Shunt type in crystalline solar cells. Prog. Photovoltaics Res. Appl. 12, 529-538.

Chatterjee, A., Keyhani, A., Kapoor, D., 2011. Identification of photovoltaic source models. IEEE Trans. Energy Convers. 26, 883-889. 
Chicco, G., Cocina, V., Di Leo, P., Spertino, F., Massi Pavan, A., 2016. Error assesment of solar irradiance forecasts and AC power from energy conversion model in grid-connected photovoltaic systems. Energies 9.

Chine, W., Mellit, A., Massi Pavan, A., Kalogirou, S.A., 2014. Fault detection method for grid-connected photovoltaic plants. Renewable Energy 66, 99-110.

Chine, W., Mellit, A., Lughi, V., Malek, A., Sulligoi, G., Massi, A., 2016. Pavan, « A novel fault diagnosis technique for photovoltaic systems based on artificial neural networks ». Renewable Energy 90, 501-512.

Choubey, P., Oudhia, A., Dewangan, R., 2012. A review: Solar cell current scenario and future trends. Recent Res. Sci. Technol. 4 (8), 99-101.

Cristaldi, L., Faifer, M., Rossi, M., Ponci, F., 2012. A simple photovoltaic panel model: characterization procedure and evaluation of the role of environmental measurements. IEEE Trans. Sustainable Energy 61, 2632-2641.

Cristaldi, L., Faifer, M., Leone, G., Vergura, S., 2015. Reference strings for statistical monitoring of the energy performance of photovoltaic fields. In: IEEE-ICCEP 2015 International Conference on Clean Electrical Power, 16-18/06/2015, Taormina, Italy, 2015.

d'Alessandro, V., Di Napoli, F., Guerriero, P., Daliento, S., 2015. An automated highgranularity tool for a fast evaluation of the yield of PV plants accounting for shading effects. Renewable Energy 83, 294-304.

Dellino, G., Laudadio, T., Mari, R., Mastronardi, N., Meloni, C., Vergura, S., 2015. Energy production forecasting in a PV plant using transfer function models. IEEE-EEEIC 2015, 10-13/06/2015, Roma, Italy.

Dolara, A., Leva, S., Manzolini, G., 2015. Comparison of different physical models for PV power output prediction. Sol. Energy 119, 83-99.

Duffie, J.A., Beckman, W.A., 1991. Solar Engineering of Thermal Processes. John Wiley \& Sons Inc., New York.

Ishaque, K., Salam, Z., Taheri, H., 2011. Simple, fast and accurate two diode model for photovoltaic modules. Sol. Energy Mater. Sol. Cells 95, 586-594.

Kichou, S., Silvestre, S., Nofuentes, G., Torres-Ramírez, M., Chouder, A., Guasch, D., 2016. Characterization of degradation and evaluation of model parameters of amorphous silicon photovoltaic modules under outdoor long term exposure. Energy 96, 231-241.

Lineykin, S., Averbukh, M., Kuperman, A., 2014. Issues in modeling amorphous silicon photovoltaic modules by single-diode equivalent circuit. IEEE Trans. Ind. Electron., 6785-6793

Lo Brano, V., Orioli, A., Ciulla, G., Di Gangi, A., 2010. An improved five-parameters model for photovoltaic modules. Sol. Energy Mater. Sol. Cells 94, 1358-1370.

Luque, A., Hegedus, S., 2003. Handbook of photovoltaic science and engineering. Chichester, UK.

Mahmoud, Y., Xiao, W., Zeineldin, H.H., 2013. A parameterization approach for enhancing PV model accuracy. IEEE Trans. Ind. Electron. 60 (12), 5708-5716.

Manganiello, P., Ricco, M., Petrone, G., Monmasson, E., Spagnuolo, G., 2014 Optimization of perturbative PV MPPT methods through online system identification. IEEE Trans. Ind. Electron. 61 (12), 6812-6821.

Markvart, T., Castaner, L., 2006. Practical Handbook of Photovoltaics. Fundamentals and applications. Oxford, UK.

Massi Pavan, A., Castellan, S., Quaia, S., Roitti, S., Sulligoi, G., 2007. Power electronic conditioning systems for industrial photovoltaic fields: centralized or string inverters?. IEEE-ICCEP, 21-23/05/2007, Capri, Italy, pp. 208-214.

Massi Pavan, A., Castellan, S., Sulligoi, G., 2009. An innovative photovoltaic field simulator for hardware-in-the-loop test of power conditioning units. IEEEICCEP, 09-11/06/2009, Capri, Italy, pp. 41-45.

Massi Pavan, A., Mellit, A., De Pieri, D., Kalogirou, S.A., 2013. A comparison between BNN and regression polynomial methods for the evaluation of the effect of soiling in large scale photovoltaic plants. Appl. Energy 108, 392-401.

Massi Pavan, A., Mellit, A., De Pieri, D., Lughi, V., 2014a. A study on the mismatch effect due to the use of different photovoltaic modules classes in large-scale solar parks. Prog. Photovoltaics: Res. Appl. 22, 332-345.

Massi Pavan, A., Mellit, A., Lughi, V., 2014b. Explicit empirical model for general photovoltaic devices: experimental validation at maximum power point. Sol. Energy 101, 105-116.
Massi Pavan, A., Lughi, V., Mellit, A., Roitti, S., Sulligoi, G., Tessarolo, A., 2014. The photovoltaic laboratory at the University of Trieste. AEIT - IEEE Italy Section, Trieste, September 2014.

Massi Pavan, A., Tessarolo, A., Barbini, N., Mellit, A., Lughi, V., 2015. The effect of manufacturing mismatch on energy production for large-scale photovoltaic plants. Sol. Energy 117, 282-289.

Miceli, R., Orioli, A., di Gangi, A., 2015. A procedure to calculate the I-V characteristics of thin-film photovoltaic modules using an explicit rational form. Appl. Energy 155, 613-628.

Moballegh, S., Jiang, J., 2014. Modeling, prediction, and experimental validations of power peaks of PV arrays under partial shading conditions. IEEE Trans. Sustainable Energy 5, 293-300.

Nofuentes, G., García Domingo, B., Muñoz, J.V., Chenlo, F., 2014. Analysis of the dependence of the spectral factor of some PV technologies on the solar spectrum distribution. Appl. Energy 113, 302-309.

Ortiz Conde, A., Lugo-Munoz, D., Garcia Sanchez, F.J., 2012. An explicit multiexponential model as an alternative to traditional solar cell models with series and shunt resistances. IEEE J. Photovoltaics 2, 261-268.

Ortiz-Conde, A., Garcia Sanchez, F.J., Muci, J., 2003. New method to extract the model parameters of a solar cells from the explicit analytic solutions of their illuminated I-V characteristics. Sol. Energy Mater. Sol. Cells 90, 352-361.

Saleem, H., Karmalkar, S., 2009. An analytical method to extract the physical parameters of a solar cell from four points on the illuminated J-V curve. IEEE Trans. Device Lett. 30, 349-352.

Sandrolini, L., Artioli, M., Reggiani, U., 2010. Numerical method for the extraction of photovoltaic module double-diode model parameters through cluster analysis. Appl. Energy 87, 442-451.

Seyedmahmoudian, M., Rahmani, R., Mekhilef, S., Oo, A.M.T., Stojcevski, A., Soon, T. K., Ghandhari, A.S., 2015. Simulation and hardware implementation of new maximum power point tracking technique for partially shaded PV systems using hybrid DEPSO method. IEEE Trans. Sustainable Energy 6, 850-861.

Spertino, F., Ciocia, A., Di Leo, P., Tommasini, R., Berardone, I., Corrado, M., Infuso, A., Paggi, M., 2015. A power and energy procedure in operating photovoltaic systems to quantify the losses according to the causes. Sol. Energy 118, 313326.

Torres Ramírez, M., Nofuentes, G., Silva, J.P., Silvestre, S., Muñoz, J.V., 2014. Study on analytical modelling approaches to the performance of thin film PV modules in sunny inland climates. Energy 73, 731-740.

Townsend, T.U., 1989. M.S. Thesis, Mechanical Engineering, U. of Wisconsin Madison. A Method for Estimating the Long-Term Performance of DirectCoupled Photovoltaic Systems.

Vergura, S., 2016. A complete and simplified datasheet-based model of PV cells in variable environmental conditions for circuit simulation. Energies 9 (5), 326.

Vergura, S., Massi Pavan, A., 2015. On the photovoltaic explicit empirical model: operations along the I-V curve. IEEE-ICCEP, 16-18/06/2015, Taormina Italy, pp. 99-104.

Vergura, S., Acciani, G., Amoruso, V., Patrono, G., Vacca, F., 2009. Descriptive and inferential statistics for supervising and monitoring the operation of PV plants. IEEE Trans. Ind. Electron. 56 (11), 4456-4464.

Vergura, S., Acciani, G., Falcone, O., 2009. Modeling defects of PV-cells by means of FEM. IEEE-ICCEP 2009, 9-11/06/2009, Capri, Italy, pp. 52-56.

Vergura, S., Acciani, G., Falcone, O., 2009. 3-D PV-cell model by means of FEM. IEEEICCEP 2009, 9-11/06/2009, Capri, Italy, pp. 35-40.

Vergura, S., Acciani, G., Falcone, O., 2012. A finite element approach to analyze the thermal effect of defects on silicon-based PV cells. IEEE Trans. Ind. Electron. 59 (10), 3860-3867.

Villalva, M.G., Gazoli, J.R., Filho, E.R., 2009. Comprehensive approach to modelling and simulation of photovoltaic arrays. IEEE Trans. Power Electron. 24, 11981208.

Ylldıran, N., Tacer, E., 2016. Identification of photovoltaic cell single diode discrete model parameters based on datasheet values. Sol. Energy 127, 175-183. 